\title{
Measurement of Partial Pressures over CdSe and CdTe by an Optical Absorption Method*
}

\author{
By Kenzo Igaki** and Masayoshi Nakano***
}

\begin{abstract}
Partial pressures of the constituent elements over $\mathrm{CdSe}(\mathrm{s})$ and $\mathrm{CdTe}(\mathrm{s})$ have been measured by using optical cells consisting of an optical path chamber and a sample chamber. Dissociation constants were $\log K_{\mathrm{CdSe}}=\log P_{\mathrm{Cd}}^{2} \times P_{\mathrm{Se}_{2}}\left(\mathrm{~atm}^{3}\right)=-33416 / T+20.43 \quad\left(707 \sim 936^{\circ} \mathrm{C}\right)$ and $\log K_{\mathrm{CdTe}}=$ $\log P_{\mathrm{Cd}}^{2} \times P_{\mathrm{Te}_{2}}\left(\mathrm{~atm}^{3}\right)=-29979 / T+19.62\left(763 \sim 908^{\circ} \mathrm{C}\right)$. Using another type of optical cell having a reservoir chamber, control of partial pressure over the sample $(\mathrm{CdSe}(\mathrm{s})$ or $\mathrm{CdTe}(\mathrm{s}))$ was attempted by regulating saturated pressure of one of the constituent elements at the reservoir temperature, $T_{\mathrm{R}}$. When $P_{t T_{\mathrm{R}}}\left(i: \mathrm{Cd}, \mathrm{Se}_{2}, \mathrm{Te}_{2}\right)$, the partial pressure at the resevoir, is larger than $P_{t}^{*}$, the partial pressure corresponding to the total pressure minimum at a given temperature, partial pressure control is effective with such a reservoir. However, when $\boldsymbol{P}_{i T_{\mathrm{R}}}$ is smaller than $\boldsymbol{P}_{i}^{*}$, partial pressure control by a reservoir is not effective, and the condition of the total pressure minimum dominates in the system.
\end{abstract}

(Received July 2, 1979)

\section{Introduction}

A small deviation from stoichiometric composition often yields a large variation in characteristic properties of compounds. For binary compounds the deviation from stoichiometry is effectively controlled by annealing the sample in the partial pressure of the constituent element regulated by the reservoir temperature ${ }^{(1)}$. The prior method ${ }^{(2)}$, which is a vapor growth technique with the reservoir containing one component, is often used to grow a crystal with the composition corresponding to the component partial pressure directly. However, the knowledge of the application limits of this reservior technique is essential in controlling the composition of the prepared specimen.

In this work, the partial pressure of the constituent element, $\mathrm{Cd}(\mathrm{g}), \mathrm{Se}_{2}(\mathrm{~g})$ or $\mathrm{Te}_{2}(\mathrm{~g})$ in the vapor phase over the binary compound, $\mathrm{CdSe}$ or CdTe, was measured by an optical absorption method on regulating the temperature of the reservoir.

* This paper was originally published in Japanese in J. Japan Inst. Metals, 42 (1978), 369.

** Department of Materials Science, Faculty of Engineering, Tohoku University, Sendai 980, Japan.

*** Graduate School, Tohoku University, Sendai 980, Japan.

\section{Experimental}

A schematic drawing of the apparatus is shown in Fig. 1. The $\mathrm{D}_{2}$-lamp is used as a light source. Light from the lamp is chopped, and absorbed by the vapor in an optical cell in the electric furnace in the shape of capital letter $\mathrm{T}$. After passing a spectrophotometer it is detected by using a lock-in amplifier. Optical absorption by $\mathrm{Cd}, \mathrm{Se}$ and $\mathrm{Te}$ in the vapor phase over $\mathrm{CdSe}$ and $\mathrm{CdTe}$ is measured in the wavelength region between $200 \mathrm{~nm}$ and $600 \mathrm{~nm}$. CdSe and CdTe crystals used in this study were synthesized from elements, $\mathrm{Cd}$, Se and $\mathrm{Te}$ of nominal purity 6-nines in a carbon coated silica ampule. Schematic drawings of optical silica cells used in this study is shown in Fig. 2. Optical path chamber is $22 \mathrm{~mm}$ in outer diameter and $L \mathrm{~mm}$

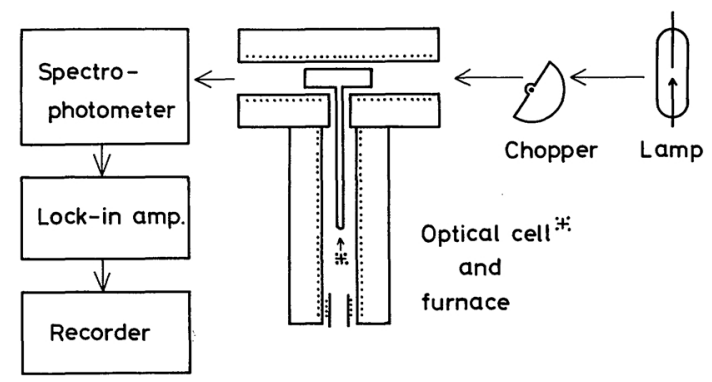

Fig. 1 Schematic drawing of the apparatus for measuring vapor pressure.

1979 Vol. 20

Trans. JIM 


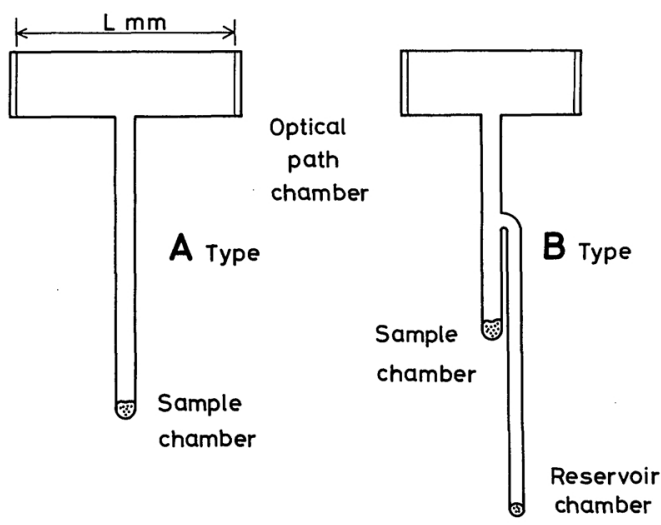

Fig. 2 Optical cells.

in length, where $L$ is $5.0,50.0,96.2$ or $150.0 \mathrm{~mm}$, and has optical flat parallel end windows. " $A$ " type cell has optical path chamber and sample chamber which holds CdSe or CdTe crystal at $30 \mathrm{~cm}$ below the optical path chamber. "B" type cell has a sample chamber which is $20 \mathrm{~cm}$ below the optical path chamber and also a reservoir chamber which holds $\mathrm{Cd}$, $\mathrm{Se}$ or $\mathrm{Te}$ at $25 \mathrm{~cm}$ below the sample position.

The magnitude of the optical absorption is given by the optical density, $D_{\lambda}$, defined by the following equation:

$$
D_{\lambda}=-\log \left(I_{\lambda} / I_{0 \lambda}\right)
$$

where $\lambda$ is the wavelength, $I_{\lambda}$ and $I_{0 \lambda}$ are the light intensity after and before absorption due to the vapor phase in the optical path chamber. Optical path temperature $T_{\mathrm{o}}$ and sample temperature $T_{\mathrm{S}}$ were measured with $\mathrm{Pt}-\mathrm{Pt} \cdot 13 \% \mathrm{Rh}$ thermocouples and reservoir temperature $T_{R}$, with a chromel-alumel thermocouple within an accuracy of $\pm 3^{\circ} \mathrm{C}$. $I_{\lambda}$ was measured after holding 1 or $2 \mathrm{~h}$ at the fixed temperature.

\section{Results}

The relations between $D_{i}$ and $P_{i}\left(i: \mathrm{Cd}, \mathrm{Se}_{2}\right.$, $\mathrm{Te}_{2}$ ) are needed for the calibration on measuring the partial pressures of constituent elements over the compounds. The optical density at a number of wavelengths at $T_{\mathrm{O}}=960^{\circ} \mathrm{C}$ is plotted in Figs. $3 \sim 5$ on a logarithmic scale against the reciprocal absolute temperature of component, $\mathrm{Cd}, \mathrm{Se}$ or Te, held in the sample chamber of "A" type cell. Cd vapor has two prominent

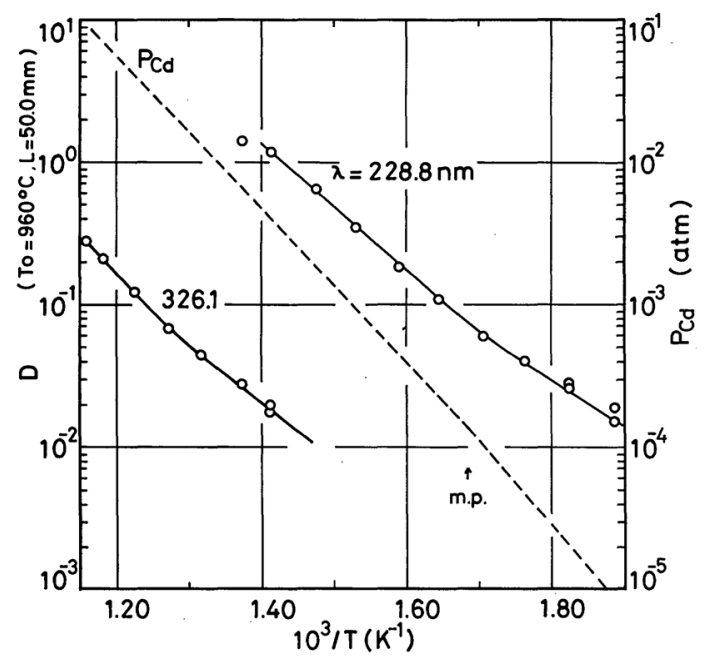

Fig. 3 Optical density of $\mathrm{Cd}(\mathrm{g})$ at two wavelengths for a $50.0 \mathrm{~mm}$ optical path at $960^{\circ} \mathrm{C}$ plotted on a logarithmic scale against the reciprocal absolute temperature of a pure $\mathrm{Cd}(\mathrm{s}$ or l) sample. The broken line gives the vapor pressure of $\mathrm{Cd}(\mathrm{s}$ or 1$)$ as read with the right hand ordinate.

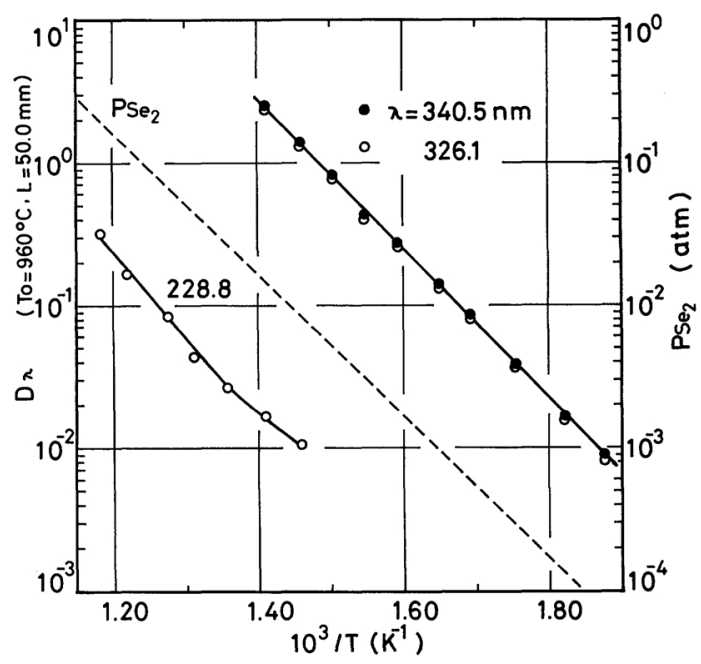

Fig. 4 Optical density of $\mathrm{Se}_{2}(\mathrm{~g})$ at a number of wavelengths for a $50.0 \mathrm{~mm}$ optical path at $960^{\circ} \mathrm{C}$ plotted on a logarithmic scale against the reciprocal absolute temperature of a pure $\mathrm{Se}(\mathrm{l})$ sample. The broken line gives the vapor pressure of $\mathrm{Se}(\mathrm{l})$ as read with the right hand ordinate.

absorption peaks at 228.8 and $326.1 \mathrm{~nm}$. Se vapor and $\mathrm{Te}$ vapor have broad absorption bands at $300 \sim 400$ and $380 \sim 500 \mathrm{~nm}$ respectively as reported by Brebrick et al. ${ }^{(3)(5)(6)}$ Absorption band maxima are at 340.5 and $418.7 \mathrm{~nm}$ respectively. According to Brebrick 


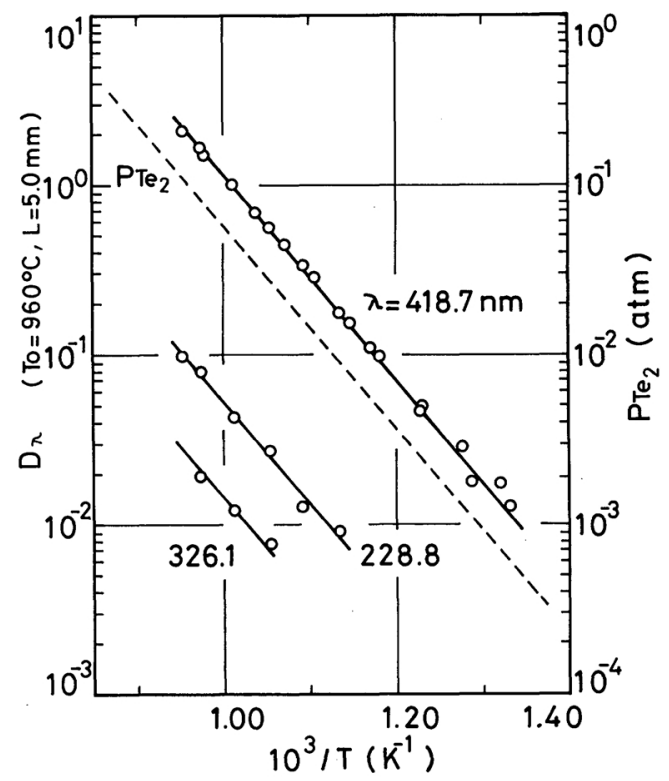

Fig. 5 Optical density of $\mathrm{Te}_{2}(\mathrm{~g})$ at a number of wavelengths for a $5.0 \mathrm{~mm}$ optical path at $960^{\circ} \mathrm{C}$ plotted on a logarithmic scale against the reciprocal absolute temperature of a pure $\mathrm{Te}(1)$ sample. The broken line gives the vapor pressure of $\mathrm{Te}(1)$ as read with the right hand ordinate.

et al. these absorption bands are regarded as being due to $\mathrm{Se}_{2}(\mathrm{~g})$ and $\mathrm{Te}_{2}(\mathrm{~g})$. Furthermore, it is known from the previous reports ${ }^{(7) \sim(9)}$ that the Se vapor and $\mathrm{Te}$ vapor are mainly composed of $\mathrm{Se}_{2}(\mathrm{~g})$ and $\mathrm{Te}_{2}(\mathrm{~g})$ (more than $98 \%$ ) respectively in the vapor pressure and the temperature $\left(960^{\circ} \mathrm{C}\right)$ used in this study. Therefore the vapor pressures of Se and Te are simply symbolized by $P_{\mathrm{Se}_{2}}$ and $P_{\mathrm{Te}_{2}}$ respectively. The optical densities at 228.8 and $326.1 \mathrm{~nm}$ are also shown in Figs. 4 and 5. Published data ${ }^{(10)}$ of the equilibrium vapor pressures as a function of temperature of the elements, Cd, Se and Te, are also shown in Figs. 3 5. Particularly in the case of Cd shown in Fig. $3, D_{\lambda}$ is not parallel with the vapor pressure. The reason for the lack of parallelism may be an insufficient resolution of the spectrometer to resolve a sharp absorption peak of monoatomic molecule like $\mathrm{Cd}(\mathrm{g})$. But the relation between $D_{\lambda}$ and temperature is observed with good reproducibility, so the calibration is made on the basis of these figures.

Observed optical density due to the vapor phase over CdSe or CdTe is caused by two

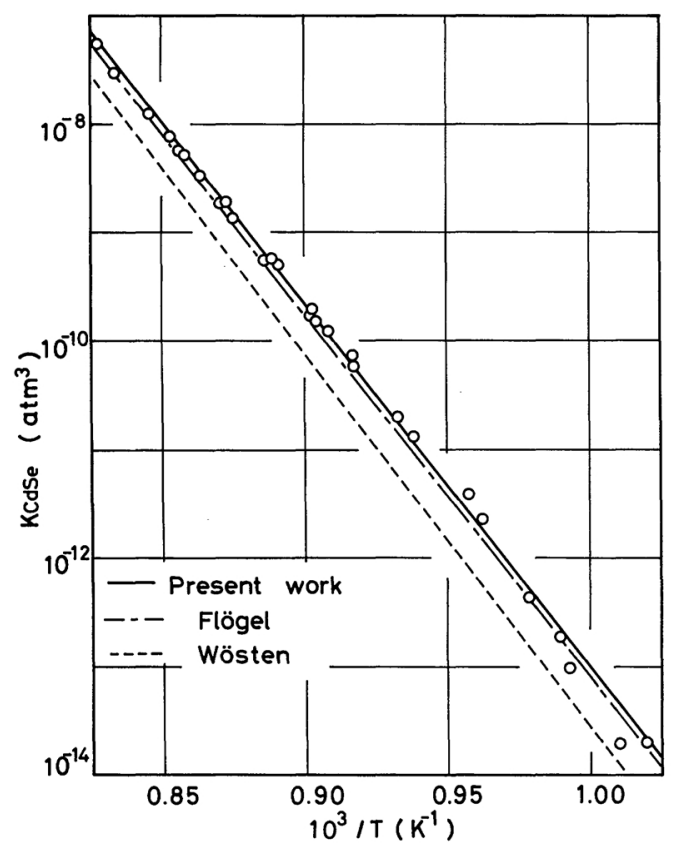

Fig. 6 Dissociation constant for $\mathrm{CdSe}(\mathrm{s})$ plotted on a logarithmic scale against the reciprocal absolute temperature.

vapor species. As the optical density due to $\mathrm{Cd}(\mathrm{g})$ was negligible at 340.5 and $418.7 \mathrm{~nm}$, where the absorption by $\mathrm{Se}_{2}(\mathrm{~g})$ and $\mathrm{Te}_{2}(\mathrm{~g})$ were measured, the data at these wavelengths shown in Figs. 4 and 5 were used to determine $P_{\mathrm{Se}_{2}}$ and $P_{\mathrm{Te}_{2}}$. The contribution of $\mathrm{Se}_{2}(\mathrm{~g})$ or $\mathrm{Te}_{2}(\mathrm{~g})$ to the optical densities at 228.8 and $326.1 \mathrm{~nm}$, where the absorption by $\mathrm{Cd}(\mathrm{g})$ was measured, was read using the data shown in Fig. 4 or 5. The partial optical density of $\mathrm{Cd}(\mathrm{g})$ at each of these wavelengths was taken as difference between the observed density and the contribution of $\mathrm{Se}_{2}(\mathrm{~g})$ or $\mathrm{Te}_{2}(\mathrm{~g})$. The value of $P_{\mathrm{Cd}}$ corresponding to each of these partial optical densities was then read using the data shown in Fig. 3.

$P_{\mathrm{Cd}}$ and $P_{\mathrm{Se}_{2}}$ or $P_{\mathrm{Te}_{2}}$ over CdSe or CdTe have been measured with " $A$ " type cells and these values give dissociation constant. $K_{\mathrm{CdSe}}$ and $K_{\mathrm{CdTe}}$ are plotted on a logarithmic scale against the reciprocal absolute temperature in Figs. 6 and 7 respectively. The data of Wösten ${ }^{(11)}$ and Flögel $^{(12)}$ obtained by using transportation method are also shown in Fig. 6. The result of this study is close to the recent data of Flögel. 


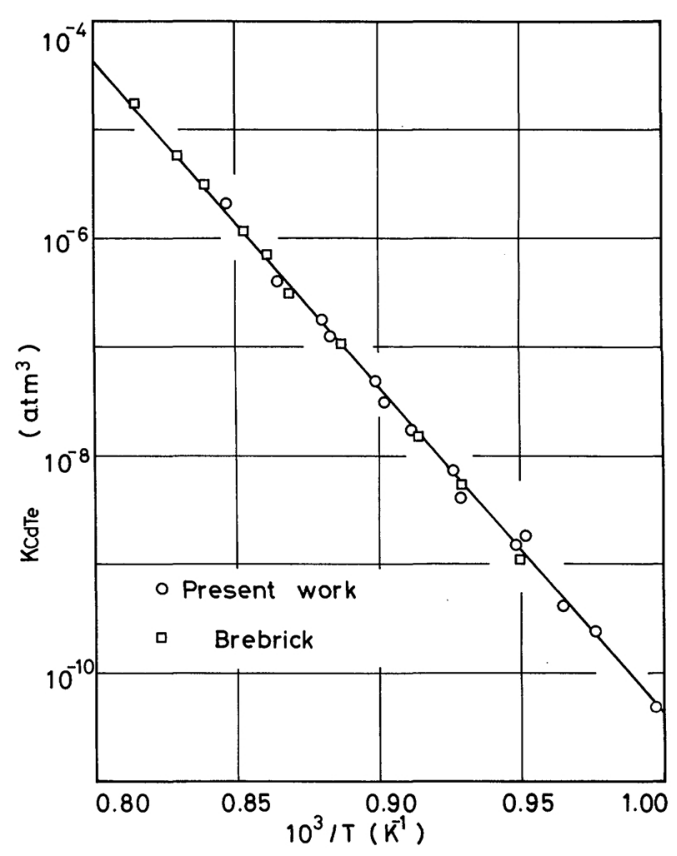

Fig. 7 Dissociation constant for CdTe(s) plotted on a logarithmic scale against the reciprocal absolute temperature.

The data obtained by Brebrick $^{(13)}$ using the optical absorption method are also shown in Fig. 7. The data of this study and of Brebrick correspond to each other and no detectable deviation between them is recognized. The solid lines in Figs. 6 and 7 are given by the following equations determined by the method of least squares:

$$
\begin{aligned}
\log K_{\mathrm{CdSe}} & =\log P_{\mathrm{Cd}}^{2} \times P_{\mathrm{Se}_{2}}\left(\mathrm{~atm}^{3}\right) \\
& =-33416 / T+20.43\left(707 \sim 936^{\circ} \mathrm{C}\right),
\end{aligned}
$$

and

$$
\begin{aligned}
\log K_{\mathrm{CdTe}} & =\log P_{\mathrm{Cd}}^{2} \times P_{\mathrm{Te}_{2}}\left(\mathrm{~atm}^{3}\right) \\
& =-29979 / T+19.62\left(763 \sim 908^{\circ} \mathrm{C}\right) .
\end{aligned}
$$

Subsequently the vapor pressure over CdSe or CdTe was measured on using " $B$ " type cell under controlled vapor pressure with a reservoir. $P_{\mathrm{Cd}}$ and $P_{\mathrm{Se}_{2}}$ over CdSe are plotted against $P_{\mathrm{Cd} T_{\mathrm{R}}}$, Cd pressure due to $\mathrm{Cd}$ reservoir, in Fig. 8 for constant $T_{\mathrm{S}}, 889^{\circ} \mathrm{C}$, and different $\mathrm{Cd}$ reservoir temperatures. The length of error bars of experimental values was estimated on the basis of scatter of points in Figs. 3 and 4.

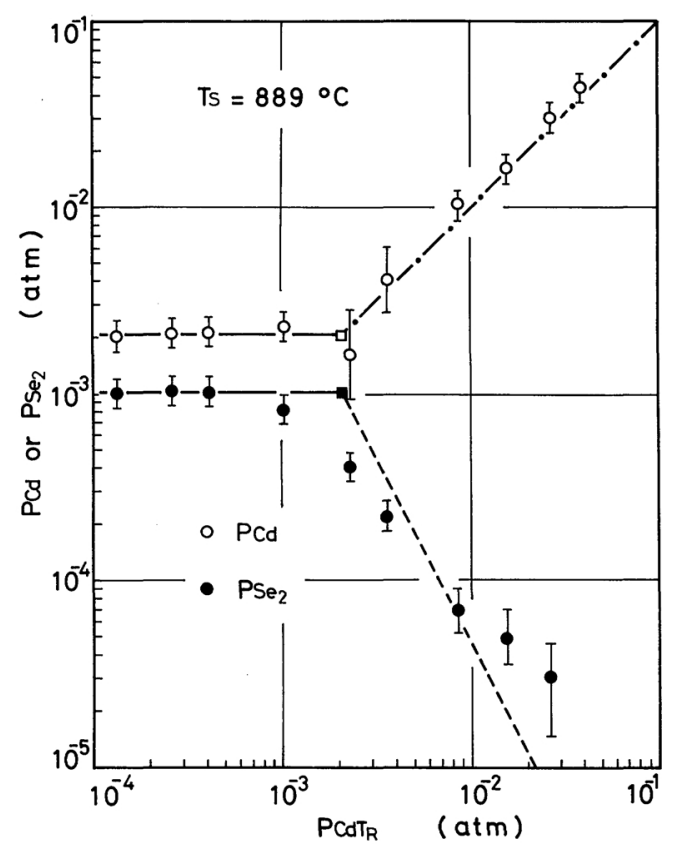

Fig. 8 Partial pressures of $\mathrm{Cd}(\mathrm{g})$ and $\mathrm{Se}_{2}(\mathrm{~g})$ over $\mathrm{CdSe}(\mathrm{s})$ at $889^{\circ} \mathrm{C}$ plotted against apparent partial pressure of $\mathrm{Cd}(\mathrm{g})$ given by a pure $\mathrm{Cd}(\mathrm{s}$ or 1$)$ reservoir temperature. $\square, P_{\mathrm{Cd}}^{*}$ and $\square, P_{\mathrm{Se}_{2}}^{*_{1}}$ correspond to the total pressure minimum.

Symbols $\square$ and $\square$ indicate $P_{\mathrm{Cd}}^{*}$ and $P_{\mathrm{Se}_{2}}^{*}$ respectively, which are the vapor pressures corresponding to those at the total pressure minimum, $\left(P_{\mathrm{Cd}}=2 P_{\mathrm{Se}_{2}}\right.$ at the minimum of the total pressure, $\left.P_{\text {tot }}=P_{\mathrm{Cd}}+P_{\mathrm{Se}_{2}}\right)$ and are plotted at the abscissa of $P_{\mathrm{Cd} T_{\mathrm{R}}}$ where $P_{\mathrm{Cd}}^{*}=P_{\mathrm{Cd} T_{\mathrm{R}}}$. The chain line shows the relation between $P_{\mathrm{Cd}}$ and $P_{\mathrm{Cd} T_{\mathrm{R}}}$ on the assumption that $P_{\mathrm{Cd} T_{\mathrm{R}}}$ controls the vapor phase over CdSe, $P_{\mathrm{Cd}}=P_{\mathrm{Cd} T_{\mathrm{R}}}$. The broken line shows the relation between $P_{\mathrm{Se}_{2}}=$ $K_{\mathrm{CdSe}} / P_{\mathrm{Cd}}^{2}$ and $P_{\mathrm{Cd} T_{\mathrm{R}}}$ on the assumption, $P_{\mathrm{Cd}}=$ $P_{\mathrm{Cd} T_{\mathrm{R}}}$. Similar expression is used in Figs. $9 \sim 11$. In the region, $P_{\mathrm{Cd}_{\mathrm{R}}}<P_{\mathrm{Cd}}^{*}, P_{\mathrm{Cd}}$ and $P_{\mathrm{Se}_{2}}$ over CdSe are nearly equal to $P_{\mathrm{Cd}}^{*}$ and $P_{\mathrm{Se}_{2}}^{*}$ respectively with no dependence on $P_{\mathrm{Cd} T_{\mathrm{R}}}$. In the other region, $P_{\mathrm{Cd} T_{\mathrm{R}}}>P_{\mathrm{Cd}}^{*}, P_{\mathrm{Cd}}$ is nearly equal to $P_{\mathrm{Cd} T_{\mathrm{R}}}$ and $P_{\mathrm{Se}_{2}}$ varies along the broken line proportional to $P_{\mathrm{Cd} T_{\mathrm{R}}}^{-2}$. Similar trend is observed in other experiments with $\mathrm{Cd}$ reservoir in the temperature range, $816^{\circ} \mathrm{C} \leqq T_{\mathrm{S}} \leqq 955^{\circ} \mathrm{C}$. The result for Se reservoir at $T_{\mathrm{S}}=950^{\circ} \mathrm{C}$ is shown in Fig. 9, where the chain line shows the relation on the assumption, $P_{\mathrm{Se}_{2}}=P_{\mathrm{Se}_{2} T_{\mathrm{R}}}$, and the broken line shows the value of $P_{\mathrm{Cd}}$ calculated 


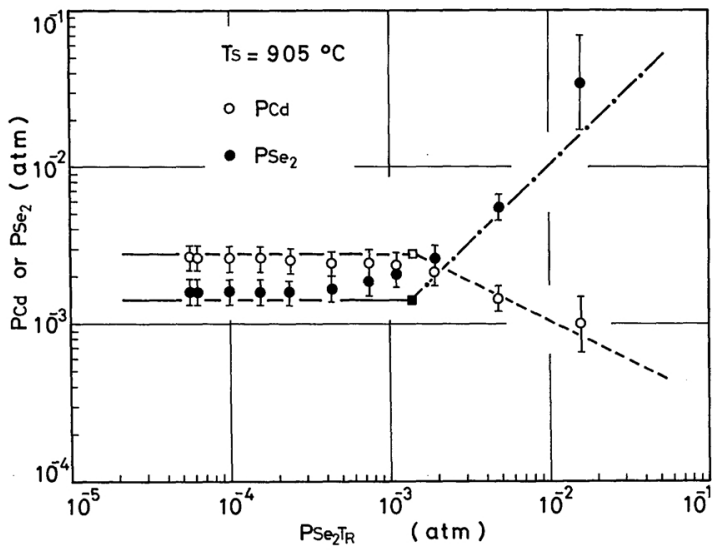

Fig. 9 Partial pressures of $\mathrm{Cd}(\mathrm{g})$ and $\mathrm{Se}_{2}(\mathrm{~g})$ over $\mathrm{CdSe}(\mathrm{s})$ at $905^{\circ} \mathrm{C}$ plotted against apparent partial pressure of $\mathrm{Se}_{2}(\mathrm{~g})$ given by a pure $\mathrm{Se}(\mathrm{l})$ reservoir temperature. $\square, P_{\mathrm{Cd}}^{*}$ and $\mathbf{\square}, P_{\mathrm{Se}_{2}}$ correspond to the total pressure minimum.

with $K_{\mathrm{CdSe}}$ and $P_{\mathrm{Se}_{2} T_{\mathrm{R}}}$. In the region, $P_{\mathrm{Se}_{2} T_{\mathrm{R}}}<$ $P_{\mathrm{Se}_{2}}^{*}, P_{\mathrm{Cd}}$ and $P_{\mathrm{Se}_{2}}$ are nearly equal to $P_{\mathrm{Cd}^{*}}^{*}$ and $P_{\mathrm{Se}_{2}}^{*}$, respectively, with no dependence on $P_{\mathrm{Se}_{2} T_{\mathrm{R}}}$. In the region, $P_{\mathrm{Se}_{2} T_{\mathrm{R}}}>P_{\mathrm{Se}_{2}}^{*}, P_{\mathrm{Se}_{2}}$ is nearly equal to $P_{\mathrm{Se}_{2} T_{\mathrm{R}}}$ and $P_{\mathrm{Cd}}$ varies along the broken line proportional to $P_{\mathrm{Se}_{2} T_{\mathrm{R}}}^{-1 / 2}$. The deviation of $P_{\mathrm{Cd}}$ and $P_{\mathrm{Se}_{2}}$ from $P_{\mathrm{Cd}}^{*}$ and $P_{\mathrm{Se}_{2}}^{*}$ in the region, $P_{\mathrm{Se}_{2} T_{\mathrm{R}}}<P_{\mathrm{Se}_{2}}^{*}$, as shown in Fig. 9 is due to the residual excess $\mathrm{Se}$ in $\mathrm{CdSe}$, because $P_{\mathrm{Se}_{2} T_{\mathrm{R}}}$ was varied from high value to low in this run. Similar trend is observed in other experiments with Se reservoir in the temperature range, $860^{\circ} \mathrm{C} \leqq T_{\mathrm{S}} \leqq 929^{\circ} \mathrm{C}$.

The results of similar measurements with CdTe sample are shown in Figs. 10 and 11. Measurements were performed with $\mathrm{Cd}$ and $\mathrm{Te}$ reservoirs in the temperature ranges, $734^{\circ} \mathrm{C} \leqq T_{\mathrm{S}} \leqq 910^{\circ} \mathrm{C}$ and $738^{\circ} \mathrm{C} \leqq T_{\mathrm{S}} \leqq 903^{\circ} \mathrm{C}$, respectively. The relation between $P_{\mathrm{Cd}}$ or $P_{\mathrm{Te}_{2}}$ over CdTe and $P_{\mathrm{Cd}_{\mathrm{R}}}$ or $P_{\mathrm{Te}_{2} T_{\mathrm{R}}}$ is similar to that obtained for CdSe.

Thus it is confirmed that partial pressure control by a reservoir is not effective in the region, $P_{i T_{\mathrm{R}}}<P_{i}^{*}$, but is effective in the region, $P_{i T_{\mathrm{R}}}>P_{i}^{*}\left(i\right.$ : molecular species, Cd, $\mathrm{Se}_{2}$ or $\left.\mathrm{Te}_{2}\right)$.

When the optical cell was taken out from the furnace, deposition of sample was usually observed between the sample chamber and the reservoir chamber due to vapor transportation caused by the temperature difference. The reason why the partial pressure over CdSe or

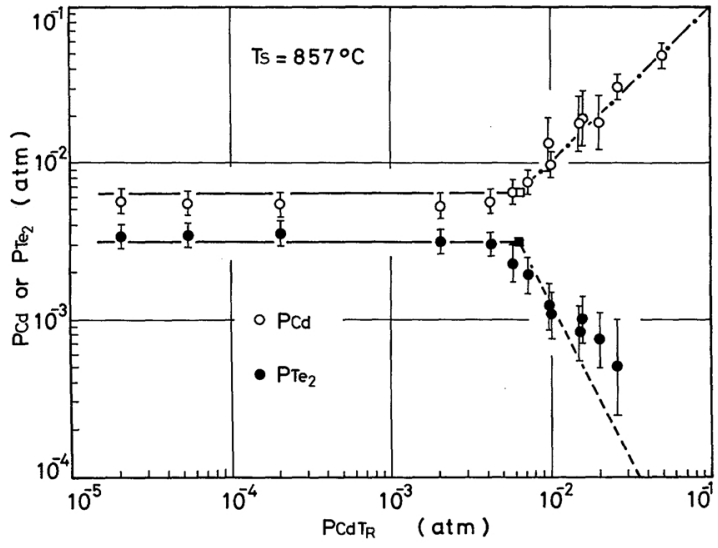

Fig. 10 Partial pressures of $\mathrm{Cd}(\mathrm{g})$ and $\mathrm{Te}_{2}(\mathrm{~g})$ over $\mathrm{CdTe}(\mathrm{s})$ at $857^{\circ} \mathrm{C}$ plotted against apparent partial pressure of $\mathrm{Cd}(\mathrm{g})$ given by a pure $\mathrm{Cd}(\mathrm{s}$ or 1$)$ reservoir temperature. $\square, P_{\mathrm{Cd}}^{*}$ and $\square, P_{\mathrm{Te}_{2}}^{*}$ correspond to the total pressure minimum.

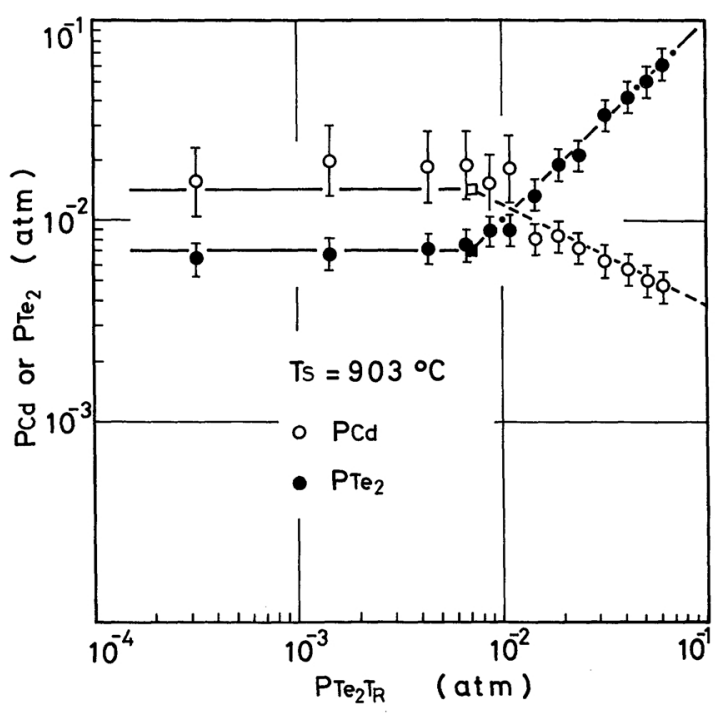

Fig. 11 Partial pressures of $\mathrm{Cd}(\mathrm{g})$ and $\mathrm{Te}_{2}(\mathrm{~g})$ over $\mathrm{CdTe}(\mathrm{s})$ at $903^{\circ} \mathrm{C}$ plotted against apparent partial pressure of $\mathrm{Te}_{2}(\mathrm{~g})$ given by a pure $\mathrm{Te}(\mathrm{l})$ reservoir temperature. $\square, P_{\mathrm{Cd}}^{*}$ and $\square, P_{\mathrm{Te}_{2}}^{*}$ correspond to the total pressure minimum.

CdTe correspond to the total pressure minimum in the region, $P_{i T_{\mathrm{R}}}<P_{i}^{*}$, is understood as follows. In this experimental region, the partial pressures due to the sample composition dominate the system, and excess component preferentially escapes from the sample through vapor transportation. When the initial sample composition is not the one corresponding to 
the total pressure minimum, the sample composition finally tends to become the one corresponding to the total pressure minimum.

\section{Summary}

When partial pressure control by a reservoir is attempted for II-VI compound, CdSe or $\mathrm{CdTe}$, in the region where component partial pressure due to a reservoir is lower than that corresponding to the total pressure minimum, partial pressure corresponding to the total pressure minimum arises in the system, that is to say, the system cannot be controlled by the apparent partial pressure regulated by reservoir temperature and partial pressure control on using a reservoir is not effective. Possible occurrence of such a situation has been pointed out in the study of the crystal growth of II-VI compound, $\mathrm{ZnSe}^{(14)}$ and in the study of IV-VI compound, $\mathrm{PbSe}^{(15)}$, containing component elements of relatively high equilibrium vapor pressure. In the present study the conditions of the occurrence of the total pressure minimum is experimentally verified from the measurements of partial pressure. It is made clear that the replenishment with replacement of reservoir elements is essential in order to get information in the whole stability range for binary compounds, especially for the compounds consisting of the component elements of relatively high equilibrium vapor pressure.

\section{Acknowledgment}

The authors take pleasure in acknowledging the useful suggestions by Dr. K. Mochizuki and Dr. Y. Noda.

\section{REFERENCES}

(1) F. A. Kröger: The Chemistry of Imperfect Crystals, North-Holland Publishing Co., Amsterdam, (1964), p. 92; K. Igaki: OYO BUTURI, 37 (1968), 664.

(2) A. C. Prior: J. Electrochem. Soc., 108 (1961), 82.

(3) R. F. Brebrick and A. J. Strauss: J. Chem. Phys., 40 (1964), 3230.

(4) R. F. Brebrick: J. Electrochem. Soc., 118 (1971), 2014.

(5) R. F. Brebrick: J. Chem. Phys., 43 (1965), 3031.

(6) R. F. Brebrick: J. Phys. Chem., 72 (1968), 1032.

(7) K. C. Mills: Thermodynamic Data for Inorganic Sulphides, Selenides and Tellurides, Butterworths, London, (1974), p. 78, 95, 720, 729.

(8) J. Berkowitz and W. A. Chupka: J. Chem. Phys., 45 (1966), 4289; 48 (1968), 5743.

(9) P. Goldfinger and M. Jeunehomme: Trans. Faraday Soc., 59 (1963), 2851.

(10) A. N. Nesmeyanov: Vapor Pressure of the Chemical Elements, Elsevier Publishing Co., Amsterdam, p. 201, 322, 327.

(11) W. J. Wösten: J. Phys. Chem., 65 (1961), 1949.

(12) Von P. Flögel: Z. anorg. allg. Chem., 370 (1969), 16.

(13) R. F. Brebrick and A. J. Strauss: J. Phys. Chem. Solid., 25 (1964), 1441.

(14) T. Kiyosawa, K. Igaki and N. Ohashi: Trans. JIM, 13 (1972), 248.

(15) N. Ohashi and K. Igaki: J. Japan. Inst. Metals, 28 (1964), 366. 